\title{
CORRESPONDENCE
}

\section{Algebra of Certainty}

SIR,--Under the heading "Value of a Hypothesis" your correspondent (Nature, 244, 329; 1973) discusses Sturrock's attempt to form strong inferences from a number of, in themselves, inconclusive observations. $\mathrm{He}$ says: "One thing to be learned from Sturrock, however, is that, even if each available item is inconclusive in itself, the resultant effect of several items may give almost completely convincing support for one solution."

This approach to certainty has been used by others, notably Cardinal Newman, as recorded in the well-known verses:

"There was a grave prelate named Newman

Whose soul was sufficient for two men ;

He said: 'In sooth,

Three doubts make a truth,'

Which he thereupon proved with acumen."

Unfortunately, Sturrock is harder to rhyme.

$$
\begin{aligned}
& \text { Yours faithfully, } \\
& \text { H. W. DAVENPORT }
\end{aligned}
$$

The University of Michigan Medical School,

Department of Physiology,

Medical Science Building,

Ann Arbor, Michigan 48104

\section{Hump Back Salmon}

SIR,-In the late 1950s the Russians undertook extensive plantings of the Pacific hump back salmon (Oncorhynchus gorbuscha, Walbaum) in rivers on the Kola Peninsula entering the Barents Sea and recaptures were made within two years, apart from Russia itself, in Norway, Iceland and the United Kingdom. At that time no recaptures were reported from Ireland.

On August 14 a male hump back salmon, measuring $60 \mathrm{~cm}$ and weighing $2 \mathrm{~kg}$, was taken by an angler from the River Moy in the north-west of Ireland. This is the first specimen of a hump back salmon to be recorded from Irish waters, all previous reports having related to deformed members of the Atlantic salmon (Salmo salar).

Yours faithfully,

A. E. J. WENT

Department of Agriculture and

Fisheries, Fisheries Division,

3 Cathal Brugha Street, Dublin 1

\section{A Question of Growth}

SIR,-I am writing this on the off chance that it might fill some minuscule gap in research, or suggest some useful line of enquiry.

For the past ten years or so, I have spent my summer holidays in Interlaken (Bernese Oberland), staying two to three weeks. On every visit, I have found that my finger nails and my hair grow at less than half the rate they grow in London, where I live. The growth rate slows down almost immediately on my arrival, and continues until I return to London, when it starts up again at the usual rate.

Interlaken is at 1,860 feet, and its very pure water is taken from the Saxeten valley, to the south-west.

I am about 6 feet tall, and rather fat, and am mostly a vegetarian. I drink sparsely in London, and a good deal in Switzerland; but otherwise my habits seem to have little to do with the matter. I am now 64 years old.

I have mentioned this peculiarity to a number of people but no one can explain it ; but it has always struck me as very odd indeed. Perhaps your readers number someone who has made a study of nail and hair growth, and who could either enlighten me, or use me as a guinea-pig.

Yours faithfully,

Charles H. Gibbs-Smith

Residence $C$,

Victoria and Albert Museum,

London SW7

\section{Announcements}

\section{University News}

Dr D. M. Smith, University of New England, has been appointed to the Chair of Geography at Queen Mary College.

Dr B. T. Donovan, Institute of Psychiatry, has been given the title of Professor of Neuroendocrinology at the University of London.

Dr D. W. Moore, Imperial College, has been given the title of Professor of Applied Mathematics at the University of London.

Dr M. L. Rutter, Institute of Psychiatry, has been appointed to the Chair of Child Psychiatry at the University of London.

\section{Appointments}

Dr R. G. Baker, British Steel Corporation, has been appointed Superintendent of the Division of Materials Applications at the National Physical Laboratory.

\section{Miscellaneous}

Dr Leo Goldberg, Kitt Peak Observatory, has been elected President of the World Astronomical Body.

Mr K. C. G. Heath, Anglo American Corporation, has been elected President of the Institution of Mining and Metallurgy.

\section{Erratum}

IN the article "Origin of Bright Spots in High Resolution Dark Field Electron Microscopy" by G. J. Brakenhoff (Nature, 243, 512; 1973) line 7 of paragraph 2 should read "The overfocus distance of the dark field bright spots is $350 \pm 80 \mathrm{~nm}$ with respect to the geometrical image plane", and the last line of paragraph 2 should read "The scatter angles for electrons to contribute to the dark field image are in between 0.001 and 0.012 radians". Paragraph 6 should read "Third, the bright points are found at overfocus in relation to the geometrical focus. Then, a plane is imaged that is, relative to the direction of travel behind the object, just where according to the present model one would expect the interference maxima".

\section{International Meetings}

October 1-3, International Conference on Land for Waste Management (M. K. Ward, Executive Secretary, International Conference on Land for Waste Management, National Research Council, Ottawa, K1A OR6, Canada).

October 2-4, Industry and Effluent (CDRA, 29 St James's Street, London SW1A 1HB).

October 2-6, Symposium on Remote Sensing in Oceanography (Dr J. P. Latham, Florida Atlantic University, Boca Raton, FI. 33432).

October 3, A Joint Meeting of the Food Group and the Microbiology, Fermentation and Enzyme Technology Group (Mr D. Hicks, Honorary Secretary, Food Group, Chief Research Manager (Food and Drink), Beecham Products Ltd., Beecham House Annexe, Great West Road, Brentford, Middlesex). 